\title{
Seasonal Influenza and Avian Influenza A(H5N1) Virus Surveillance among Inpatients and Outpatients, East Jakarta, Indonesia, 2011-2014
}

\author{
Kathryn E. Lafond, ${ }^{1}$ Catharina Y. Praptiningsih, ${ }^{1}$ Amalya Mangiri, Misriyah Syarif, \\ Romadona Triada, Ester Mulyadi, Chita Septiawati, Vivi Setiawaty, \\ Gina Samaan, Aaron D. Storms, Timothy M. Uyeki, A. Danielle Iuliano
}

During October 2011-September 2014, we screened respiratory specimens for seasonal and avian influenza $A(H 5 N 1)$ virus infections among outpatients with influenza-like illness and inpatients with severe acute respiratory infection (SARI) in East Jakarta, an Indonesia district with high incidence of $\mathrm{H} 5 \mathrm{~N} 1$ virus infection among poultry. In total, $31 \%$ $(1,875 / 6,008)$ of influenza-like illness case-patients and $15 \%$ $(571 / 3,811)$ of SARI case-patients tested positive for influenza virus. Influenza $A(H 1 N 1) p d m 09$, influenza $A(H 3 N 2)$, and influenza $B$ virus infections were detected in all 3 years, and the epidemic season extended from November through May. Although $28 \%(2,810 / 10,135)$ of case-patients reported exposure to poultry, only 1 SARI case-patient with an H5N1 virus infection was detected. Therefore, targeted screening among case-patients with high-risk poultry exposures (e.g., a recent visit to a live bird market or close proximity to sick or dead poultry) may be a more efficient routine surveillance strategy for H5N1 virus in these types of settings.

Ceasonal influenza contributes substantially to acute $\checkmark$ respiratory disease in Indonesia and across the world. Influenza virus causes $\approx 3-5$ million cases of severe illness (1) and $\approx 291,000-646,000$ respiratory deaths each year globally, most occurring in lower-income countries (2). In

Author affiliations: University of Tampere, Tampere, Finland (K.E. Lafond); US Centers for Disease Control and Prevention, Atlanta, Georgia, USA (K.E. Lafond, A.D. Storms, T.M. Uyeki, A.D. Iuliano); US Centers for Disease Control and Prevention, Jakarta, Indonesia (C.Y. Praptiningsih, A. Mangiri, E. Mulyadi); Ministry of Health, Jakarta (M. Syarif, R. Triada, C. Septiawati, V. Setiawaty); Australian National University, Canberra, Capital Territory, Australia (G. Samaan)

DOI: https://doi.org/10.3201/eid2511.181844
Indonesia, published data suggest that influenza virus infection has a substantial effect on population health and the healthcare system, causing both inpatient and outpatient respiratory illness (3-5). Among the more densely populated western and central islands of Indonesia, influenza activity peaks in December and January, correlating with the rainy season. However, limited data from 1 district of Jakarta suggest that a longer peak in influenza activity occurs December-May, with multiple influenza viruses co-circulating (4).

In addition to seasonal influenza $\mathrm{A}$ and $\mathrm{B}$ epidemics, highly pathogenic avian influenza $\mathrm{A}(\mathrm{H} 5 \mathrm{~N} 1)$ virus also circulates among poultry in Indonesia (O). Jakarta Province is a hub for Indonesia's commercial poultry trade, and East Jakarta ( 1 of its 5 districts) is the main entry point for national poultry shipments (7). During 2005-2017, Indonesia detected and reported $200 \mathrm{H} 5 \mathrm{~N} 1$ infections in humans, of which $168(84 \%)$ were fatal (8). Although the number of infections in humans has decreased in Indonesia since 2015 , this country still has the second highest number of reported cases (after Egypt) and the highest reported casefatality proportion among all countries reporting $\mathrm{H} 5 \mathrm{~N} 1 \mathrm{vi}-$ rus infections in humans. In East Jakarta, 12 of 13 H5N1 cases reported in humans during 2005-2015 were fatal (9).

Although influenza surveillance capacity in Indonesia has increased $(5,10)$, national policies for influenza vaccination and antiviral use are limited. Influenza vaccination is recommended only for Hajj pilgrims and antivirals only for those with H5N1 virus infection $(11,12)$. Thus, multiyear data are needed to explore trends in seasonal influenza and avian H5N1 virus infections among humans. Data are particularly needed in regions of Indonesia where highly

${ }^{1}$ These authors contributed equally to this article. 
pathogenic avian influenza $\mathrm{A}(\mathrm{H} 5 \mathrm{~N} 1)$ viruses are prevalent among poultry and the risk for poultry-to-human $\mathrm{H} 5 \mathrm{~N} 1$ virus transmission is elevated. Here, we describe the findings from a 3-year enhanced surveillance platform among inpatients and outpatients of clinics in East Jakarta for both seasonal influenza and avian influenza $\mathrm{A}(\mathrm{H} 5 \mathrm{~N} 1)$ viruses.

\section{Methods}

During October 2011-September 2014, we conducted enhanced influenza surveillance in East Jakarta to monitor influenza-like illness (ILI) among case-patients seeking treatment at 4 public primary health centers and severe acute respiratory infection (SARI) among inpatients at 6 hospitals (3 public and 3 private, all equipped with an intensive care unit [ICU]). We selected hospitals on the basis of their location within or bordering the district and the number of persons admitted for respiratory disease. We selected outpatient sites (among 10 subdistrict-level clinics present in East Jakarta) on the basis of proximity to live bird markets. ILI surveillance was conducted Monday-Friday, and surveillance staff used the case definition of recorded temperature $\geq 38^{\circ} \mathrm{C}$ with cough or sore throat to identify ILI case-patients. SARI surveillance was conducted every day in adult and pediatric wards (excluding surgery, obstetric, and gynecology) at all 6 hospitals. Hospital staff used the 2005 World Health Organization (WHO) Integrated Management of Childhood Illness case definition for pneumonia for case-patients $<5$ years of age (13) to identify SARI cases in this age group. To identify SARI in case-patients $\geq 5$ years of age, staff used the 2011 WHO SARI case definition, which defines SARI as fever (measured temperature $\geq 38^{\circ} \mathrm{C}$ or subjective report of feverishness), disease onset within 7 days, and $\geq 1$ of the following signs or symptoms: cough, sore throat, or shortness of breath (14). We defined elevated respiratory rate as $>60$ breaths/min for case-patients $<2$ months of age, $\geq 50$ breaths $/ \mathrm{min}$ for case-patients 2-11 months of age, $\geq 40$ breaths $/ \mathrm{min}$ for case-patients $1-4$ years of age, $\geq 35$ breaths/min for case-patients 5-7 years of age, $\geq 31$ breaths $/ \mathrm{min}$ for case-patients $8-11$ years of age, $\geq 28$ breaths/min for case-patients $12-14$ years of age, and $\geq 25$ breaths $/ \mathrm{min}$ for case-patients $\geq 15$ years of age $(15,16)$. Staff obtained written consent from all enrolled ILI and SARI case-patients; surveillance staff completed case forms for and collected specimens from all enrolled case-patients. We collected data on demographic characteristics, clinical presentation, and exposure to poultry. Poultry exposure questions included questions on the exposures listed in the Indonesia case definition for suspected H5N1 virus infection (i.e., touching healthy, sick, or dead poultry or poultry products; slaughtering or cleaning poultry; or contact with chicken manure), as well as on poultry ownership, visiting live poultry markets, and neighborhood poultry die-offs (4). For SARI case-patients, we additionally collected data on risk factors for severe disease (chronic conditions, pregnancy, and smoking status), self-reported influenza vaccine use, and duration and outcome of hospitalization.

Surveillance staff collected nasal and throat swab samples from all enrolled ILI and SARI case-patients and sent them to 2 laboratories in Jakarta for influenza diagnosis (Provincial Health Laboratory of Daerah Khusus Ibukota [DKI] Jakarta and the Infectious Disease Hospital Sulianti Saroso Laboratory). Quality control testing was provided by the National Institute of Health Research and Development, a WHO-designated National Influenza Centre. These laboratories tested samples by real-time reverse transcription PCR (RT-PCR) following the US Centers for Disease Control and Prevention in-house real-time RT-PCR protocol for detection and characterization of influenza viruses. All specimens were tested for influenza A and B viruses, and influenza A virus-positive specimens were further subtyped for influenza $\mathrm{A}(\mathrm{H} 1 \mathrm{~N} 1) \mathrm{pdm} 09$ and $\mathrm{A}(\mathrm{H} 3 \mathrm{~N} 2)$ viruses; specimens that were negative for these subtypes were then tested for $\mathrm{H} 5 \mathrm{~N} 1$ virus.

All surveillance and laboratory records were entered into a secured web-based electronic reporting system (Surveilans ILI-SARI DKI Jakarta) hosted by the DKI Jakarta Provincial Health Office (Jakarta, Indonesia). All eligible ILI and SARI case-patients were enumerated and reported through this electronic system on a weekly basis. The central project team trained site-level surveillance staff at the beginning of the project and conducted regular monitoring visits throughout the study to ensure thorough case ascertainment and data quality assurance at each site. Complete information on surveillance and data management methods were published previously (4).

We analyzed bivariate comparisons using $\chi^{2}$ and Fisher exact tests. For time variables (e.g., time from illness onset to seeking care, duration of hospitalization), we determined median values and evaluated differences using the Mann-Whitney U test. We compared influenza virus detection across seasons qualitatively and identified time periods with elevated influenza virus circulation by determining the percentage of influenza virus-positive ILI or SARI episodes among all ILI or SARI episodes each week. We used poultry contact data to determine the percentage of case-patients who met the Indonesia case definition for suspected H5N1 virus infection (i.e., acute lower respiratory tract illness with fever and recent exposure to poultry or a human with a suspected $\mathrm{H} 5 \mathrm{~N} 1$ virus infection within 7 days of illness onset, based on WHO case definition) (17). We defined children as persons $<18$ years of age. We conducted all statistical analyses using SPSS version 21 (IBM, https://www.ibm.com).

This surveillance project was reviewed and considered to be routine public health surveillance by the Ministry of Health (Jakarta, Indonesia) and US Centers for 
Disease Control and Prevention (Atlanta, Georgia, USA). Thus, our surveillance was exempted from institutional review board approval.

\section{Results}

During October 2011-September 2014, we enrolled 6,064 ILI case-patients ( $1 \%$ of 476,537 outpatient visits) (Table $1)$. Most $(87 \%, 5,261 / 6,064)$ of these case-patients were $<18$ years of age. Because of case-patient refusal, we could not collect 56 respiratory specimens (from $1 \%$ of those enrolled). Of the 6,008 ILI specimens collected, 1,875 (31\%) were positive for influenza virus. Median time from illness onset to outpatient visit among all ILI case-patients was 1 (interquartile range [IQR] 1-2) day (Table 2). Influenza virus-positive ILI case-patients (median age 7 [IQR 3-13] years) were older than influenza virus-negative ILI casepatients (median age 4 [IQR $1-8]$ years; $\mathrm{p}<0.001$ by $\chi^{2}$ test). Among ILI case-patients, influenza virus-negative case-patients (19\%) were more likely than influenza viruspositive case-patients $(12 \% ; \mathrm{p}<0.001)$ to have an elevated respiratory rate. More than one quarter $(29 \%, 546 / 1,875)$ of influenza virus-positive ILI case-patients met the national case definition for suspected H5N1 virus infection.

We enrolled 4,071 SARI case-patients ( $2 \%$ of 184,576 hospitalizations) (Table 1). We could not collect 260 (6\%) SARI specimens because of case-patient refusal or

Table 1. Characteristics of ILI and SARI case-patients in study of incidence of seasonal and avian influenza $A(H 5 N 1)$ virus infections, East Jakarta, Indonesia, October 2011-September 2014*

\begin{tabular}{lcc}
\hline Characteristic & ILI, $\mathrm{n}=6,064$ & SARI, $\mathrm{n}=4,071$ \\
\hline Age, $\mathrm{y}$ & & \\
$<5$ & $2,715(44.8)$ & $1,414(35)$ \\
$5-17$ & $2,546(42.0)$ & $650(16)$ \\
$18-49$ & $705(11.6)$ & $1,298(32)$ \\
$50-64$ & $85(1.4)$ & $463(11)$ \\
$\geq 65$ & $13(0.2)$ & $246(6)$ \\
\hline Age, $\mathrm{y}$, median (IQR) & $5(2-9)$ & $17(2-40)$ \\
\hline Sex & & \\
M & $2,930(48)$ & $2,205(54)$ \\
F & $3,134(52)$ & $1,866(46)$ \\
\hline Specimens collected and & $6,008(99)$ & $3,811(94)$ \\
tested for influenza & & \\
\hline Influenza virus positive & & \\
Any & $1,875 / 6,008(31)$ & $571 / 3,811(15)$ \\
A & $1,057 / 1,875(56)$ & $330 / 571(58)$ \\
A(H3N2) & $605 / 1,057(57)$ & $177 / 330(53.6)$ \\
A(H1N1)pdm09 & $452 / 1,057(43)$ & $152 / 330(46.1)$ \\
A(H5N1) & 0 & $1 / 330(0.3)$ \\
B & $827 / 1,875(44)$ & $241 / 571(42)$ \\
\hline Met Indonesia case & $1,943(32)$ & $867(21)$
\end{tabular}

Met Indonesia case

definition for suspected

avian $\mathrm{H} 5 \mathrm{~N} 1$ virus infection $†$

*Values are no. (\%), except where indicated otherwise. ILI and SARI were defined as described in the text. ILI, influenza-like illness; IQR, interquartile range; SARI, severe acute respiratory infection.

†Acute lower respiratory tract illness with fever and recent exposure to poultry (i.e., touching healthy, sick, or dead poultry or poultry products; slaughtering or cleaning poultry; or contact with chicken manure) or a human with a suspected H5N1 virus infection within 7 days of illness onset. discharge before specimen collection; thus, we excluded these case-patients. Median time from illness onset to hospital admission was 3 days for children and adults, and median time from illness onset to specimen collection was 5 days (Table 3 ). Of the 3,811 SARI specimens collected, 571 (15\%), including 1 positive for H5N1 virus, were positive for influenza virus (Table 1). Among all influenza virus-positive SARI case-patients, 97 (17\%) met the national case definition for suspected H5N1 virus infection (Table 3).

The H5N1 virus-positive case-patient was a 33-yearold man (Table 4) with an onset of illness of June 1, 2014. On June 4, he was admitted into a hospital, where he received a diagnosis of pneumonia (chest radiograph data unavailable) and was enrolled into surveillance; his respiratory specimen was collected on June 6. On June 13, he was transferred to a designated referral hospital, where he began antiviral treatment and died on June 14. He was obese but had no other concurrent medical condition; exposure history included visiting a live bird market, where he purchased live poultry within 7 days before hospital admission. This case was not linked to any documented bird outbreaks. No animal or environmental specimen collection occurred because of the length of time that elapsed before linkage to a live poultry market and because of rapid turnover of poultry through these markets.

SARI case-patients were 0-90 years of age. A higher proportion of SARI cases among children 5-17 years of age

Table 2. Characteristics of ILI case-patients by influenza virus positivity, East Jakarta, Indonesia, October 2011-September $2014^{*}$

\begin{tabular}{|c|c|c|c|}
\hline \multirow[b]{2}{*}{ Characteristic } & \multicolumn{2}{|c|}{ Influenza virus positive } & \multirow[b]{2}{*}{$p$ value } \\
\hline & $\begin{array}{c}\text { Yes, } \\
\mathrm{n}=1,875\end{array}$ & $\begin{array}{c}\text { No, } \\
n=4,133\end{array}$ & \\
\hline \multicolumn{4}{|l|}{ Sex } \\
\hline M & $900(48)$ & $2,007(49)$ & 0.687 \\
\hline $\mathrm{F}$ & $975(52)$ & $2,126(51)$ & \\
\hline \multicolumn{4}{|l|}{ Age, y† } \\
\hline$<5$ & $562(30.0)$ & $2,150(52.0)$ & \\
\hline $5-17$ & 915 (48.8) & $1,592(38.5)$ & \\
\hline $18-49$ & $350(18.7)$ & 341 (8.3) & \\
\hline $50-64$ & $41(2.2)$ & $44(1.1)$ & \\
\hline$\geq 65$ & $7(0.4)$ & $6(0.1)$ & \\
\hline Age, y, median (IQR) & $7(3-13)$ & $4(1-8)$ & $<0.001$ \\
\hline $\begin{array}{l}\text { Time from illness onset to } \\
\text { outpatient visit, d, median } \\
\text { (IQR) }\end{array}$ & $1(1-2)$ & $1(1-2)$ & 0.526 \\
\hline Elevated respiratory rate $\neq$ & $229(12)$ & 796 (19) & $<0.001$ \\
\hline $\begin{array}{l}\text { Met Indonesia case definition } \\
\text { for suspected avian influenza } \\
\text { A(H5N1) virus infection§ }\end{array}$ & $546(29)$ & $1,387(34)$ & $<0.001$ \\
\hline \multicolumn{4}{|c|}{$\begin{array}{l}\text { *Values are no. (\%), except where indicated otherwise. ILI was defined as } \\
\text { stated in the text. ILI, influenza-like illness; IQR, interquartile range. } \\
\text { †Percentages in group do not always add up to } 100 \% \text { because of } \\
\text { rounding. } \\
\text { †Defined as described in the text. } \\
\text { §Acute lower respiratory tract illness with fever and recent exposure to } \\
\text { poultry (i.e., touching healthy, sick, or dead poultry or poultry products; } \\
\text { slaughtering or cleaning poultry; or contact with chicken manure) or a } \\
\text { human with a suspected H5N1 virus infection within } 7 \text { days of illness onset. }\end{array}$} \\
\hline
\end{tabular}


Table 3. Characteristics of case-patients with SARI, by influenza virus positivity, East Jakarta, Indonesia, October 2011-September $2014^{*}$

\begin{tabular}{|c|c|c|c|}
\hline \multirow[b]{2}{*}{ Characteristic } & \multicolumn{2}{|c|}{ Influenza virus positive } & \multirow[b]{2}{*}{$p$ value } \\
\hline & Yes, $n=571$ & No, $n=3,240$ & \\
\hline Sex & & & 0.816 \\
\hline M & $310(54)$ & $1,742(54)$ & \\
\hline $\mathrm{F}$ & $261(46)$ & $1,498(46)$ & \\
\hline \multicolumn{4}{|l|}{ Age, y† } \\
\hline$<5$ & $164(29)$ & $1,109(34)$ & \\
\hline $5-17$ & $111(19)$ & $503(16)$ & \\
\hline $18-49$ & $186(33)$ & $1,065(33)$ & \\
\hline $50-64$ & $78(14)$ & $364(11)$ & \\
\hline$\geq 65$ & $32(6)$ & $199(6)$ & \\
\hline Age, y, median (IQR) & $21(4-43)$ & $18(2-40)$ & 0.019 \\
\hline Time from illness onset to admission, $d$, median (IQR) & $3(2-4)$ & $3(2-5)$ & 0.020 \\
\hline Time from illness onset to specimen collection, $d$, median (IQR) & $5(4-6)$ & $5(4-7)$ & 0.012 \\
\hline \multicolumn{4}{|l|}{ Concurrent medical conditions } \\
\hline$\geq 1$ & $123(22)$ & $779(24)$ & 0.195 \\
\hline Asthma & $55(10)$ & $253(8)$ & 0.294 \\
\hline Tuberculosis & $43(8)$ & $345(11)$ & 0.045 \\
\hline Diabetes & $27(5)$ & $141(4)$ & 0.007 \\
\hline Influenza vaccination in past year & $2(0)$ & $36(1)$ & 0.066 \\
\hline Pregnancy & $5 / 93(5)$ & $22 / 568(4)$ & 0.497 \\
\hline Current smoker & $75(13)$ & $466(14)$ & 0.7 \\
\hline Elevated respiratory rate§ & $139(24)$ & $1,061(33)$ & $<0.001$ \\
\hline Chest radiograph-confirmed pneumoniaף & $177 / 481(37)$ & $1,153 / 2,799(41)$ & 0.07 \\
\hline Met Indonesia case definition for suspected influenza $A(H 5 N 1)$ virus infection\# & $97(17)$ & $721(22)$ & 0.005 \\
\hline Sought care before admission $* *$ & & & 0.007 \\
\hline Yes & $180 / 276(65)$ & $1,112 / 1,514(73)$ & \\
\hline No & $96 / 276(35)$ & $402 / 1,514(27)$ & \\
\hline Primary discharge diagnosis available & $517(91)$ & $2,912(90)$ & 0.625 \\
\hline Pneumonia & $132 / 517(26)$ & $996 / 2,912(34)$ & $<0.001$ \\
\hline Typhoid & $103 / 517(20)$ & $303 / 2,912(10)$ & \\
\hline Unspecified febrile IIIness & $57 / 517(11)$ & $189 / 2,912(6)$ & \\
\hline Upper respiratory tract infection & $43 / 517(8)$ & $235 / 2,912(8)$ & \\
\hline Tuberculosis & $32 / 517(6)$ & $311 / 2,912(11)$ & \\
\hline Discharge form completed & $568(99)$ & $3,211(99)$ & 0.465 \\
\hline \multicolumn{4}{|l|}{ Medication during hospitalization } \\
\hline Antibiotics & $554 / 568(98)$ & $3,093 / 3,211(96)$ & 0.14 \\
\hline Oseltamivir & $14 / 568(2)$ & $22 / 3,211(1)$ & $<0.001$ \\
\hline Corticosteroid & $10 / 568(2)$ & $116 / 3,211(4)$ & 0.064 \\
\hline Intensive care unit & $6 / 568(1)$ & $101 / 3,211(3)$ & 0.006 \\
\hline Mechanical ventilation & $6 / 568(1)$ & $76 / 3,211(2)$ & 0.049 \\
\hline Length of hospitalization, $d$, median (IQR) & $4(3-6)^{\prime}$ & $5(3-8)$ & $<0.001$ \\
\hline Outcome & & & 0.075 \\
\hline Recovered & $550 / 568(97)$ & $3,022 / 3,211(94)$ & \\
\hline Died & $10 / 568(2)$ & $103 / 3,211(3)$ & \\
\hline Other†† & $8 / 568(1)$ & $86 / 3,211(3)$ & \\
\hline
\end{tabular}

*Values are no. (\%), except where indicated. SARI was defined as stated in the text. IQR, interquartile range; SARI, severe acute respiratory infection.

†Percentages in group do not always add up to $100 \%$ because of rounding.

†Among female case-patients $15-49$ years of age.

§Defined as described in the text.

TAmong those with a chest radiograph performed.

\#Acute lower respiratory tract illness with fever and recent exposure to poultry (i.e., touching healthy, sick, or dead poultry or poultry products;

slaughtering or cleaning poultry; or contact with chicken manure) or a human with a suspected H5N1 virus infection within 7 days of illness onset.

${ }^{* *}$ Among those for which prehospitalization care-seeking behaviors were known.

††Includes forced discharge and referrals.

and adults 50-64 years of age were influenza virus-positive compared with other age groups $\left(\mathrm{p}=0.016\right.$ by $\chi^{2}$ test) (Table 3 ). Adults $\geq 65$ years of age comprised $6 \%$ of all influenza virus-positive and influenza virus-negative SARI cases. Concurrent medical conditions, such as tuberculosis $(10 \%, 388 / 3,811)$, asthma $(8 \%, 308 / 3,811)$, and diabetes $(4 \%, 168 / 3,811)$, were reported among $24 \%(902 / 3,811)$ of SARI case-patients; of these conditions, only diabetes was more commonly associated with influenza virus infection $(\mathrm{p}=0.007)$. Data on healthcare seeking before admission were available for about half $(46 \%, 1,790 / 3,811)$ of SARI case-patients. Influenza virus-negative SARI case-patients $(73 \%, 1,112 / 1,514)$ were more likely than influenza viruspositive case-patients $(65 \%, 180 / 276)$ to have sought care before hospitalization $(\mathrm{p}=0.007)$. Overall, $38(1 \%)$ SARI case-patients reported receiving the influenza vaccine in the previous 12 months, of whom 36 (95\%) had a negative influenza virus test finding. 
Table 4. Characteristics of SARI case-patients with severe influenza, East Jakarta, Indonesia, October 2011-September 2014*

\begin{tabular}{|c|c|c|c|c|c|c|c|}
\hline $\begin{array}{l}\text { Case- } \\
\text { patient no. }\end{array}$ & $\begin{array}{l}\text { Age, } \\
\text { y/sex }\end{array}$ & $\begin{array}{c}\text { Influenza virus } \\
\text { detected }\end{array}$ & Diagnosis & $\begin{array}{l}\text { Influenza vaccine } \\
\text { in previous year }\end{array}$ & Underlying conditions & $\begin{array}{l}\text { ICU or HCU } \\
\text { admission }\end{array}$ & Outcome \\
\hline 1 & $50 / \mathrm{M}$ & $\mathrm{A}(\mathrm{H} 3 \mathrm{~N} 2)$ & $\begin{array}{c}\text { Suspected } \mathrm{A}(\mathrm{H} 5 \mathrm{~N} 1) \\
\text { infection }\end{array}$ & No & $\begin{array}{l}\text { Smoker, diabetes, } \\
\text { heart disease }\end{array}$ & Yes & Recovered \\
\hline 2 & $33 / \mathrm{M}$ & $\mathrm{A}(\mathrm{H} 5 \mathrm{~N} 1)$ & Pneumonia & No & Obesity & Unknown & Died \\
\hline 3 & 83/M & B & Pneumonia & No & $\begin{array}{c}\text { Smoker, diabetes, } \\
\text { heart disease, asthma }\end{array}$ & No & Died \\
\hline 4 & 70/M & $\mathrm{A}(\mathrm{H} 3 \mathrm{~N} 2)$ & Pneumonia & No & Smoker & No & Died \\
\hline 5 & $66 / \mathrm{M}$ & $\mathrm{A}(\mathrm{H} 1 \mathrm{~N} 1) \mathrm{pdm} 09$ & Pneumonia & Unknown & Unknown & Yes & Died \\
\hline 6 & $0.5 / F$ & B & Pneumonia & No & None recorded & Yes & Referred \\
\hline 7 & $1 / \mathrm{M}$ & $\mathrm{A}(\mathrm{H} 3 \mathrm{~N} 2)$ & Pneumonia & No & None recorded & Yes & Recovered \\
\hline 8 & $2 / F$ & $\mathrm{~A}(\mathrm{H} 1 \mathrm{~N} 1) \mathrm{pdm} 09$ & Febrile illness & No & None recorded & No & Died \\
\hline 9 & $64 / F$ & $\mathrm{~A}(\mathrm{H} 3 \mathrm{~N} 2)$ & Febrile illness & No & $\begin{array}{l}\text { Diabetes, heart } \\
\text { disease, asthma }\end{array}$ & No & Died \\
\hline 10 & $59 / \mathrm{M}$ & $\mathrm{A}(\mathrm{H} 3 \mathrm{~N} 2)$ & $\begin{array}{l}\text { Chronic obstructive } \\
\text { pulmonary disease }\end{array}$ & No & $\begin{array}{l}\text { Smoker, kidney } \\
\text { disease, asthma }\end{array}$ & No & Died \\
\hline 11 & $62 / \mathrm{M}$ & $\mathrm{A}(\mathrm{H} 3 \mathrm{~N} 2)$ & $\begin{array}{l}\text { Congestive heart } \\
\text { failure exacerbation }\end{array}$ & No & $\begin{array}{l}\text { Smoker, heart disease, } \\
\text { chronic lung disease }\end{array}$ & No & Died \\
\hline 12 & 39/M & $\mathrm{A}(\mathrm{H} 1 \mathrm{~N} 1) \mathrm{pdm} 09$ & $\begin{array}{l}\text { Suspected } A(H 5 N 1) \\
\text { infection }\end{array}$ & No & Smoker & Yes & Died \\
\hline 13 & $63 / F$ & $\mathrm{~A}(\mathrm{H} 1 \mathrm{~N} 1) \mathrm{pdm} 09$ & Tuberculosis & No & Tuberculosis, asthma & No & Died \\
\hline 14 & $1 / \mathrm{M}$ & A(H1N1)pdm09 & Anemia, malnutrition & No & None recorded & Yes & Recovered \\
\hline
\end{tabular}

Chest radiograph-confirmed pneumonia was documented for $35 \%(1,330 / 3,811)$ of SARI case-patients (Table $3)$. Of case-patients with known primary discharge diagnoses, pneumonia $(33 \%, 1,128 / 3,429)$ was the most common diagnosis, followed by typhoid $(12 \%, 406 / 3,429)$. Almost all $(96 \%, 3,647 / 3,811)$ SARI case-patients received antibiotics during hospitalization. Only 2\% (14/568) of influenza virus-positive SARI case-patients and $1 \%(22 / 3,211)$ of influenza virus-negative case-patients with data on medication use were treated with oseltamivir. Median duration of hospital stay was slightly longer for adults (5 days) than children ( 4 days; $p<0.001$ ) and influenza virus-negative ( 5 days) than influenza virus-positive ( 4 days; $p<0.001$ ) case-patients. Overall, 3\% $(107 / 3,779)$ of case-patients with a completed discharge form had been admitted to the ICU; ICU admission was less common among influenza virus-positive case-patients $(1 \%, 6 / 568)$ than influenza virus-negative case-patients $(3 \%, 101 / 3,211 ; \mathrm{p}=0.006)$. Of the 6 case-patients with influenza who were admitted to an ICU, 3 were children and 3 were adults (Table 4). One of these adult case-patients had concurrent medical conditions, and 2 were smokers. At the time of discharge, $95 \%(3,572 / 3,779)$ of SARI case-patients had recovered (Table 3). In total, 113 SARI case-patients died; 10 were positive for influenza virus. Of those 10 deaths, 9 were associated with seasonal influenza viruses and 1 with $\mathrm{H} 5 \mathrm{~N} 1$ virus. Two SARI case-patients with severe influenza had a discharge diagnosis of suspected H5N1; both had seasonal influenza virus infection.

Collectively among ILI and SARI case-patients, influenza $\mathrm{A}(\mathrm{H} 1 \mathrm{~N} 1)$ pdm09, influenza $\mathrm{A}(\mathrm{H} 3 \mathrm{~N} 2)$, and influenza B viruses were detected in all 3 years (Figure). The percentage of ILI case-patients who were influenza virus positive during year $1(35 \%, 1,131 / 3,278)$ was slightly higher than the percentages positive during years $2(27 \%$, $427 / 1,562)$ and $3(27 \%, 317 / 1,168)$. The percentage of SARI case-patients who were influenza virus positive was consistent across all 3 years: $15 \%(276 / 1,787)$ in year 1 , $14 \%(153 / 1,122)$ in year 2 , and $16 \%(142 / 902)$ in year 3 . Each year, the percentage of samples positive for influenza virus per week started increasing in November, peaked in January or February, and declined in March but persisted through May. Influenza B virus infections were typically identified later in each season. Each year, the rate of influenza virus-positive samples per week peaked around $72 \%-85 \%$ for ILI and $38 \%-50 \%$ for SARI.

\section{Discussion}

During this 3-year period of enhanced surveillance, influenza viruses were commonly detected among ILI and SARI case-patients in East Jakarta, representing 31\% of ILI visits and $15 \%$ of SARI hospitalizations, many of which were chest radiograph-confirmed pneumonia. Although many persons met the Indonesia case definition for suspected avian $\mathrm{H} 5 \mathrm{~N} 1$ virus infection because of their interaction with poultry, only 1 case of $\mathrm{H} 5 \mathrm{~N} 1$ virus infection was identified. Within 7 days before illness onset, this H5N1 case-patient had visited a live bird market, a type of poultry exposure reported among other persons with $\mathrm{H} 5 \mathrm{~N} 1$ virus infection in Indonesia; this type of exposure was reported among only $4 \%$ of SARI case-patients in this surveillance.

One of the primary objectives of this project was to systematically test both inpatients and outpatients for H5N1 virus infection. Although the case-fatality proportion reported for humans with $\mathrm{H} 5 \mathrm{~N} 1$ virus infection in Indonesia is high, underdetection in less severely ill patients was still 


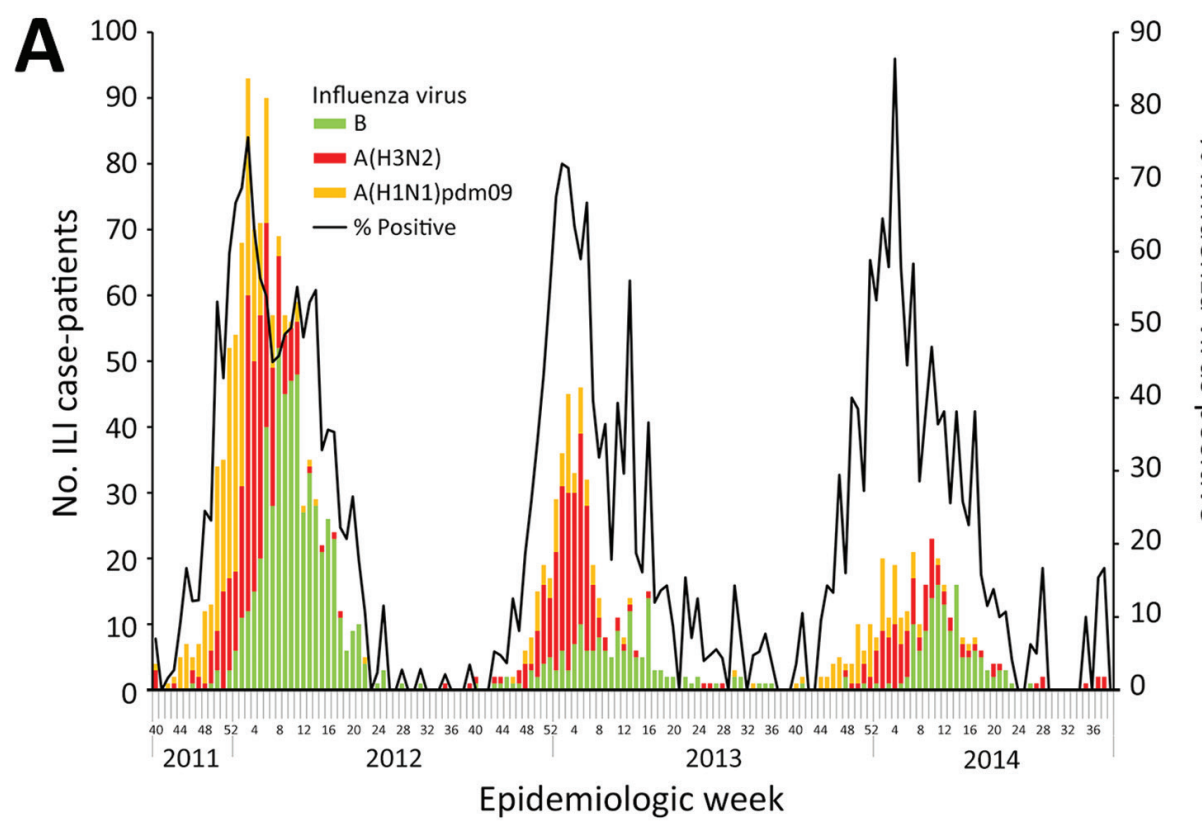

Figure. Seasonal and avian influenza $\mathrm{A}(\mathrm{H} 5 \mathrm{~N} 1)$ viruspositive ILI (A) and SARI (B) case-patients by clinical ㅇ presentation and epidemiologic इ week, East Jakarta, Indonesia, 글 2014. D ILI and SARI were defined as N stated in the text. ILI, influenza$\leqq$ like illness; SARI, severe acute $\overline{\bar{C}}$ respiratory infection.

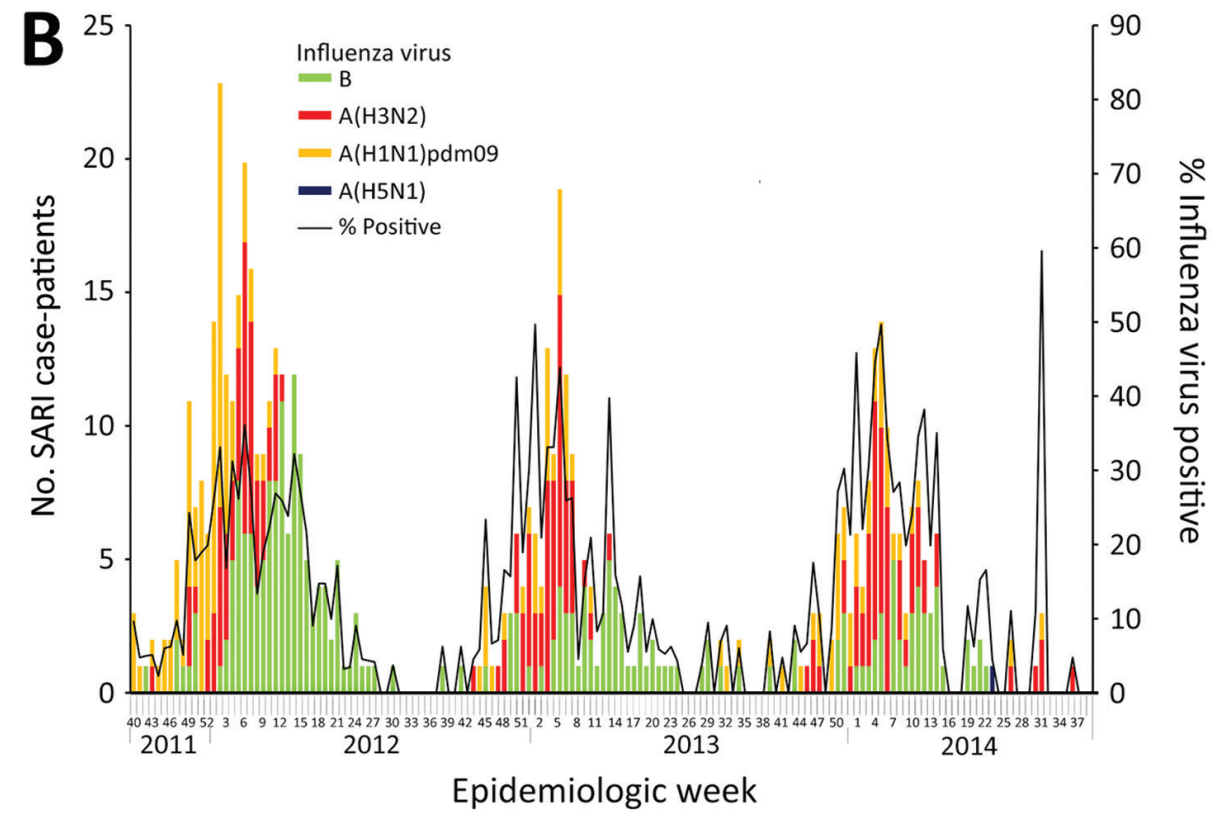

a possibility. Given that fatal outcomes are relatively rare, the ubiquity of exposure to poultry in parts of this country prohibits rigorous screening of all respiratory patients for H5N1 virus infection by sophisticated laboratory diagnostic methods such as RT-PCR. Our detection of only 1 casepatient with $\mathrm{H} 5 \mathrm{~N} 1$ virus infection in this high-risk district with endemic $\mathrm{H} 5 \mathrm{~N} 1$ virus circulation among poultry provides evidence to suggest that the likelihood of underascertainment in high-risk areas of Indonesia is low. Routine influenza surveillance in Indonesia involves inpatient and outpatient facilities, identification of SARI and ILI cases, and RT-PCR diagnostic testing; however, this surveillance is not specifically targeted to areas with endemic $\mathrm{H} 5 \mathrm{~N} 1$ virus circulation, and the volume of samples tested is much lower than the volume tested in this project.

Contrary to the infrequent detection of avian H5N1 virus, seasonal influenza A and B viruses were major contributors to medically treated respiratory illnesses in this population. Influenza $\mathrm{A}(\mathrm{H} 3 \mathrm{~N} 2)$, influenza $\mathrm{A}(\mathrm{H} 1 \mathrm{~N} 1) \mathrm{pdm} 09$, and influenza $\mathrm{B}$ viruses were all identified, and no single virus type or influenza A virus subtype predominated in any year. In this region, influenza A and B viruses were most frequently detected during the beginning of each calendar year during the rainy season. Months of peak seasonal influenza virus circulation were consistent across all 3 years and covered at least half of each year. These long seasons 
comprised consecutive peaks of influenza A and B viruses, similar to the pattern seen in US surveillance systems (18). The correspondence of influenza virus circulation with the rainy season is also consistent with evidence from other tropical countries of southern and southeastern Asia, including India and Thailand (19), as well as with previous outpatient influenza surveillance data from other parts of Indonesia (3).

In the study population, ILI case-patients were typically young children, and SARI case-patients included both children and adults. This observation is consistent with the age distribution reported by influenza surveillance platforms in other countries of Asia, such as the Philippines and Mongolia (20,21). Although older adults are more frequently identified in inpatient surveillance platforms in high-income settings (22), adults $\geq 65$ years of age comprised only $6 \%$ of SARI case-patients in our platform. Several factors should be considered when interpreting this finding. First, this finding is consistent with the relatively young age structure of the Jakarta population, where only $5 \%$ of persons are $\geq 60$ years of age (23). In addition, we conducted routine monitoring and validation activities to ensure enrollment of all eligible SARI case-patients, so the low number of case-patients enrolled in this age group is unlikely to be attributable to underenrollment. Instead, this trend might reflect differences in clinical presentation of older adults (who might not always meet the SARI case definition), decreased healthcare seeking by older adults, or a high threshold for admission by physicians. In this community, we previously conducted a survey on healthcareseeking practices and found reported hospitalizations to be higher in older adults than younger adults and children, although the older adult population comprised a small proportion of the surveyed population (24).

In addition to age distribution differences between inpatients and outpatients, influenza virus detection status also differed by age. The youngest children with ILI and SARI were less likely to be influenza virus positive; influenza virus detection was more frequent among older children and adults. This trend is consistent with findings from a global meta-analysis on pediatric influenza hospitalizations (25) and is likely driven by the high prevalence of respiratory syncytial virus among children $<1$ year of age; this virus causes a large proportion of hospitalizations among children $<5$ years of age. Although we did not test respiratory specimens for respiratory syncytial virus, this pathogen has been shown to differentially infect young children who are also at high risk for SARI.

Less than one quarter of influenza virus-positive SARI case-patients reported underlying conditions, such as asthma, tuberculosis, or diabetes, and a small number of SARI case-patients were pregnant women. These findings might be a reflection of care-seeking patterns, particularly of pregnant women, who might prefer to receive care in private maternity hospitals. Our observation of a low percentage of pregnant women with influenza is in contrast with other published findings, such as those from routine SARI surveillance in South Africa, where pregnancy was identified as a risk factor for influenza-associated hospitalization (26). Concurrent medical conditions were also more prevalent among influenza virus-positive SARI casepatients in South Africa (35\%), although surveillance in other locations, such as Damanhour, Egypt (27), revealed lower prevalences of concurrent conditions $(19 \%)$ than that found in our study (22\%). These differences might reflect baseline population variability in prevalence of diseases or variability in the types of persons seeking care at the facilities participating in surveillance.

Although use of antibiotics was common among patients in this study, only $2 \%$ of influenza virus-positive and $1 \%$ of influenza virus-negative SARI case-patients received antiviral treatment with oseltamivir. Oseltamivir is typically prescribed by physicians who suspect their patient has an $\mathrm{H} 5 \mathrm{~N} 1$ virus infection, per the Indonesia national policy for antiviral use (12). However, treating hospitalized influenza patients with oseltamivir is clinically beneficial regardless of whether the infection is seasonal or pandemic influenza virus, and recommendations outside of Indonesia include initiation of antiviral treatment as soon as possible for hospitalized patients with seasonal influenza $(28,29)$. Likewise, the report of influenza vaccination among casepatients was low, probably because of the lack of a national influenza vaccination program in Indonesia, aside from the recommendation for vaccination for Hajj travelers.

The surveillance platform in this study, involving an urban district within the capital province of Jakarta, was specifically selected for its high prevalence of $\mathrm{H} 5 \mathrm{~N} 1$ viruses in poultry (30); therefore, our findings cannot be generalized to all of Indonesia. Although routine surveillance in other districts might potentially detect even lower percentages of patients with $\mathrm{H} 5 \mathrm{~N} 1$ virus infection, likelihood of detection through a surveillance system varies by location and over time, and the true risk for infection cannot be known. Confirmed $\mathrm{H} 5 \mathrm{~N} 1$ virus infections in humans decreased in Indonesia in the 2010s; infections peaked in 2006 with 55 cases, and only 3 cases were identified during 2015-2018. This decrease in $\mathrm{H} 5 \mathrm{~N} 1$ virus infections in humans has also been observed in other countries where the virus is endemic in poultry. In addition, only a fraction of patients with seasonal influenza or avian $\mathrm{H} 5 \mathrm{~N} 1$ virus infection will seek care, and those who do seek care might not meet the typical surveillance case definition or might no longer be shedding detectable influenza virus in the upper respiratory tract by the time they provide a respiratory specimen. Avian $\mathrm{H} 5 \mathrm{~N} 1$ viruses, in particular, preferentially bind receptors in the lower respiratory tract and can be missed in upper respiratory tract 
specimen collection. Last, our results are reliant on selfreport of risk factors, such as poultry exposure and chronic medical conditions, meaning we could be underestimating the frequency of these risk factors, although recall is unlikely to differ between those with and without influenza virus infection. Despite these limitations, we believe our findings provide valuable insight into patterns of seasonal influenza virus circulation and severe respiratory disease in this urban setting in Indonesia.

In conclusion, seasonal influenza was found to be a key contributor to outpatient and inpatient respiratory disease in this urban setting of Indonesia, where avian $\mathrm{H} 5 \mathrm{~N} 1$ viruses are frequently detected among poultry. In contrast, avian $\mathrm{H} 5 \mathrm{~N} 1$ virus infection was only detected in 1 SARI case-patient, despite rigorous and systematic screening of both inpatients with SARI and outpatients with ILI. In settings like East Jakarta, where poultry exposure is common, our findings support restricting RT-PCR testing for H5N1 viruses to sick patients with unsubtypeable influenza A virus infection and those with high-risk poultry exposures, such as a recent visit to a live bird market or close proximity to sick or dead poultry. Knowledge about the prevalence of seasonal influenza and timing of the local influenza season could also be leveraged by policy makers, public health officials, and healthcare providers to improve risk communication and develop appropriate prevention and control measures, such as early empiric antiviral use and optimally timed influenza vaccination activities.

\section{Acknowledgments}

We acknowledge the following colleagues for their contributions, support, and encouragement: clinical surveillance staff at the 10 participating sites (Haji Pondok Gede Hospital, Islam Pondok Kopi Hospital, Harapan Bunda Hospital, Pasar Rebo Hospital, Budhi Asih Hospital, Persahabatan Hospital, Matraman Health Center, Kramat Jati Health Center, Pulogadung Health Center, and Duren Sawit Health Center) and laboratory staff at the Provincial Health Laboratory of DKI Jakarta, Balai Besar Teknik Kesehatan Lingkungan Jakarta Laboratory, Infectious Disease Hospital Sulianti Saroso Laboratory, and National Institute of Health Research and Development of Indonesia. We also thank staff at DKI Jakarta Provincial Health Office, the East Jakarta District Health Office, and the Zoonosis Sub Directorate Ministry of Health Indonesia and colleagues at Regional Emerging Diseases Intervention Centre, the Food and Agriculture Organization of the United Nations, Ministry of Agriculture Indonesia, US Agency for International Development, and the US Agency for International Development Deliver Project.

This project was funded by the US Centers for Disease Control and Prevention cooperative agreement IP000346.

\section{About the Author}

Ms. Lafond is an epidemiologist with the International Epidemiology and Response Team in the Influenza Division, National Center for Immunization and Respiratory Diseases, Centers for Disease Control and Prevention, Atlanta, Georgia, USA. Her primary research interests are influenza disease burden and vaccine effectiveness, with a focus on low- and middleincome countries.

\section{References}

1. World Health Organization. Fact sheet: influenza (seasonal). 2018 [cited 2018 Nov 30]. https:/www.who.int/news-room/fact-sheets/ detail/influenza-(seasonal)

2. Iuliano AD, Roguski KM, Chang HH, Muscatello DJ, Palekar R, Tempia S, et al.; Global Seasonal Influenza-associated Mortality Collaborator Network. Estimates of global seasonal influenza-associated respiratory mortality: a modelling study. Lancet. 2018;391:1285-300. http://dx.doi.org/10.1016/ S0140-6736(17)33293-2

3 Kosasih H, Roselinda, Nurhayati, Klimov A, Xiyan X, Lindstrom S, et al. Surveillance of influenza in Indonesia, 2003-2007. Influenza Other Respir Viruses. 2013;7:312-20. https://doi.org/10.1111/j.1750-2659.2012.00403.x

4. Storms AD, Kusriastuti R, Misriyah S, Praptiningsih CY, Amalya M, Lafond KE, et al. The East Jakarta Project: surveillance for highly pathogenic avian influenza A(H5N1) and seasonal influenza viruses in patients seeking care for respiratory disease, Jakarta, Indonesia, October 2011-September 2012. Epidemiol Infect. 2015;143:3394-404. https://doi.org/10.1017/ S0950268815000771

5. Susilarini NK, Haryanto E, Praptiningsih CY, Mangiri A, Kipuw N, Tarya I, et al. Estimated incidence of influenza-associated severe acute respiratory infections in Indonesia, 2013-2016. Influenza Other Respir Viruses. 2018;12:81-7. https://doi.org/10.1111/ irv.12496

6. Daniels P, Wiyono A, Sawitri E, Poermadjaja B, Sims LD. H5N1 highly pathogenic avian influenza in Indonesia: retrospective considerations. Curr Top Microbiol Immunol. 2013;365:171-84. https://doi.org/10.1007/82_2012_265

7. Food and Agriculture Organization. Approaches to controlling, preventing and eliminating $\mathrm{H} 5 \mathrm{~N} 1$ highly pathogenic avian influenza in endemic countries. 2011 [cited 2018 Nov 30]. http://www.fao.org/3/i2150e/i2150e00.htm

8. World Health Organization. Cumulative number of confirmed human cases of avian influenza $\mathrm{A}(\mathrm{H} 5 \mathrm{~N} 1)$ reported to $\mathrm{WHO}$, 2003-2018. 2018 Mar 2 [cited 2018 Nov 30]. http://www.who.int/ entity/influenza/human_animal_interface/2018_03_02_tableH5N1. pdf?ua $=1$

9. DKI Jakarta Provincial Health Office. Policy of harmonization of epidemiology and virology (H5N1 and seasonal influenza) surveillance based on sentinel in East Jakarta. Presented at: East Jakarta Project stakeholder meeting; 2015 Sep 30; Jakarta, Indonesia.

10. Hanafusa S, Muhadir A, Santoso H, Tanaka K, Anwar M, Sulistyo ET, et al. A surveillance model for human avian influenza with a comprehensive surveillance system for localpriority communicable diseases in South Sulawesi, Indonesia. Trop Med Health. 2012;40:141-7. https://doi.org/10.2149/ tmh.2012-10

11. Pane M, Imari S, Alwi Q, Nyoman Kandun I, Cook AR, Samaan G. Causes of mortality for Indonesian Hajj pilgrims: comparison between routine death certificate and verbal autopsy findings. PLoS One. 2013;8:e73243. https://doi.org/10.1371/journal.pone.0073243 
12. Kosasih H, Bratasena A, Pangesti K, Laras K, Samaan G. Managing seasonal influenza: oseltamivir treatment policy in Indonesia? Acta Med Indones. 2014;46:58-65.

13. World Health Organization Department of HIV/AIDS, World Health Organization Department of Child and Adolescent Health and Development. WHO recommendations on the management of diarrhoea and pneumonia in HIV-infected infants and children: integrated management of childhood illness. Geneva: The Organization; 2010 [cited 2018 Nov 30]. https://www.who.int/hiv/ $\mathrm{pub} / \mathrm{children} / 9789241548083$

14. World Health Organization. WHO global technical consultation: global standards and tools for influenza surveillance. 2011 Mar 8-10 [cited 2018 Nov 30]. https://www.who.int/influenza/ resources/documents/technical_consultation

15. Bonafide CP, Brady PW, Keren R, Conway PH, Marsolo K, Daymont C. Development of heart and respiratory rate percentile curves for hospitalized children. Pediatrics. 2013;131:e1150-7. https://doi.org/10.1542/peds.2012-2443

16. Cretikos MA, Bellomo R, Hillman K, Chen J, Finfer S, Flabouris A. Respiratory rate: the neglected vital sign. Med J Aust. 2008;188:657-9.

17. World Health Organization. WHO case definitions for human infections with influenza A(H5N1) virus. 2006 Aug 29 [cited 2018 Nov 30]. http://www.who.int/influenza/resources/documents/ case_definition2006_08_29

18. World Health Organization. Influenza. FluNet - CHARTS. Influenza virus detections. 2019 [cited 2018 Nov 30]. https://www.who.int/influenza/gisrs_laboratory/flunet/charts

19. Saha S, Chadha M, Al Mamun A, Rahman M, Sturm-Ramirez K, Chittaganpitch $\mathrm{M}$, et al. Influenza seasonality and vaccination timing in tropical and subtropical areas of southern and southeastern Asia. Bull World Health Organ. 2014;92:318-30. https://doi.org/10.2471/BLT.13.124412

20. Burmaa A, Kamigaki T, Darmaa B, Nymadawa P, Oshitani H. Epidemiology and impact of influenza in Mongolia, 2007-2012. Influenza Other Respir Viruses. 2014;8:530-7. https://doi.org/ 10.1111/irv. 12268

21. Tallo VL, Kamigaki T, Tan AG, Pamaran RR, Alday PP, Mercado ES, et al. Estimating influenza outpatients' and inpatients' incidences from 2009 to 2011 in a tropical urban setting in the Philippines. Influenza Other Respir Viruses. 2014;8:159-68. https://doi.org/10.1111/irv.12223

22. Jain S, Self WH, Wunderink RG, Fakhran S, Balk R, Bramley AM, et al.; Centers for Disease Control and Prevention EPIC Study Team. Community-acquired pneumonia requiring hospitalization among U.S. Adults. N Engl J Med. 2015;373:415-27. https://doi.org/10.1056/NEJMoa1500245
23. Badan Pusat Statistik. Population by age group, urban/rural area, and sex, DKI Jakarta Province [in Indonesian]. 2010 [cited 2018 Nov 30]. http://sp2010.bps.go.id/index.php/site/ tabel?tid $=263 \&$ wid $=3100000000$

24. Praptiningsih CY, Lafond KE, Wahyuningrum Y, Storms AD, Mangiri A, Iuliano AD, et al. Healthcare-seeking behaviors for acute respiratory illness in two communities of Java, Indonesia: a cross-sectional survey. J Epidemiol Glob Health. 2016;6:77-86. https://doi.org/10.1016/j.jegh.2016.01.002

25. Lafond KE, Nair H, Rasooly MH, Valente F, Booy R, Rahman M, et al.; Global Respiratory Hospitalizations - Influenza Proportion Positive (GRIPP) Working Group. Global role and burden of influenza in pediatric respiratory hospitalizations, 1982-2012: a systematic analysis. PLoS Med. 2016;13:e1001977. https://doi.org/10.1371/journal.pmed.1001977

26. Tempia S, Walaza S, Moyes J, Cohen AL, von Mollendorf C, Treurnicht FK, et al. Risk factors for influenza-associated severe acute respiratory illness hospitalization in South Africa, 2012-2015. Open Forum Infect Dis. 2017;4:ofw262. https://doi.org/10.1093/ofid/ofw262

27. Rowlinson E, Dueger E, Mansour A, Azzazy N, Mansour H, Peters L, et al. Incidence and etiology of hospitalized acute respiratory infections in the Egyptian Delta. Influenza Other Respir Viruses. 2017;11:23-32. https://doi.org/10.1111/irv.12409

28. Muthuri SG, Venkatesan S, Myles PR, Leonardi-Bee J, A 1 Khuwaitir TS, Al Mamun A, et al.; PRIDE Consortium Investigators. Effectiveness of neuraminidase inhibitors in reducing mortality in patients admitted to hospital with influenza A H1N1pdm09 virus infection: a meta-analysis of individual participant data. Lancet Respir Med. 2014;2:395-404. https://doi.org/10.1016/S2213-2600(14)70041-4

29. Uyeki TM, Bernstein HH, Bradley JS, Englund JA, File TM Jr, Fry AM, et al. Clinical practice guidelines by the Infectious Diseases Society of America: 2018 update on diagnosis, treatment, chemoprophylaxis, and institutional outbreak management of seasonal influenza. Clin Infect Dis. 2019;68:e1-47. https://doi.org/10.1093/cid/ciy866

30. Indriani R, Samaan G, Gultom A, Loth L, Irianti S, Adjid R, et al. Environmental sampling for avian influenza virus A (H5N1) in live-bird markets, Indonesia. Emerg Infect Dis. 2010;16:1889-95. https://doi.org/10.3201/eid1612.100402

Address for correspondence: Kathryn E. Lafond, Centers for Disease Control and Prevention, 1600 Clifton Rd NE, Mailstop A-32, Atlanta, GA 30329-4027, USA; email: klafond@cdc.gov 